\title{
Újévi köszöntô
}

\author{
Nagy Levente - Tóth Balázs - Ádám József
}

DOI: $\underline{10.30921 / G K .73 .2021 .1 .1}$

Absztrakt: Az írás az Agrárminisztérium Földügyi és Térinformatikai Föosztálya, a Miniszterelnökség Ingatlannyilvántartási és Térképészeti Fôosztálya valamint a Magyar Földmérési, Térképészeti és Távérzékelési Társaság vezetôinek évértékelô és az új év tekintetében feladatismertetô összefoglalója. A földmérés és térképészet ágazati irányitását érintő mélyreható közigazgatási átalakitás után továbbra is az ágazat múködését meghatározó jogszabályok módositásának elôkészitése volt az egyik legfontosabb feladat 2020-ban is. Az új esztendóben elvégzendô feladatok közül a föhatóságok életében változatlanul kiemelt jelentốséggel bír a tiszta és egyértelmú földtulajdon-viszonyok kialakítása, ezen belül a folyamatban lévó részaránykiadási eljárások belátható idôn belüli lezárása, az osztatlan közös tulajdon megszüntetésére irányuló program folytatása valamint az ingatlan-nyilvántartási ügyintézés egyszerúsítése és elektronikus csatornákra történó átterelése. A Magyar Földmérési, Térképészeti és Távérzékelési Társaság tevékenységére 2020-ban erōsen rányomta bélyegét a Covid-19 koronavírus okozta világjárvány (pandémia) hazánkat is sújtó elsó és második hulláma. A Társaság a céljainak megvalósítása érdekében folytatott munkáját - kis késlekedéssel - eredményesen helyezte át az internet által biztositott virtuális térbe. Erról tanúskodnak sikeresen megtartott on-line konferenciák és testületi rendezvények.

Abstract: This paper is a summary of the annual evaluations and forthcoming tasks by the heads of the Department of Land Administration and Geoinformation in the Ministry of Agriculture, the Department of Land Registration and Mapping in the Office of the Prime Minister, and the Hungarian Society of Surveying, Mapping and Remote Sensing. After the radical administrative changes in the sectorial management of surveying and mapping, one of the most important tasks - in addition to forming the operation of the new organizations - was to prepare the modification of laws regulating the operation of this sector in 2020 too. The forming of transparent and clear land ownership, including the completion of delivering the partial proportions in process within a reasonable time, the continuation of the programme of terminating the undivided common properties and the implementation of the e-real estate project are tasks that are of primary importance in the life of the supreme authorities in the new year. The activity of the Hungarian Society of Surveying, Mapping and Remote Sensing was greatly affected by the first and second waves of the Covid-19 pandemic, which hit Hungary too in 2020. The Society has, though with some delay, effectively moved its activity of realizing its objectives to the virtual space offered by the internet. The online conferences and corporate events bear witness to the success of this transformation.

Kulcsszavak: földmérés és térképészet ágazati irányítása, eredmények 2020-ban, feladatok 2021-ben

Keywords: sectorial management of surveying and mapping, results in 2020, tasks in 2021

\section{Tisztelt Olvasók!} Kedves Kollégák!

Egy több szempontból rendhagyó és mozgalmas, de szokás szerint sok munkával töltött év van mögöttünk, ugyanakkor az új évben is fontos új feladatok megvalósítása vár ránk. Az új esztendô alkalmából az Agrárminisztérium Földügyi és Térinformatikai Fốosztálya, a Miniszterelnökség Ingatlan-nyilvántartási és Térképészeti Fóosztálya, valamint a Magyar Földmérési, Térképészeti és Távérzékelési Társaság vezetése nevében szeretettel köszöntjük a Geodézia és Kartográfia folyóirat minden kedves olvasóját, az MFTTT tagságát, valamint a szakterület valamennyi kollégáját. Sikerekben gazdag új évet kívánunk a szakmai szervezeteknek, intézményeknek, gazdasági társaságoknak is, amelyek a földmérés, a térképészet, a térinformatika, az ingatlan-nyilvántartás, a földügy és a távérzékelés területén végzett munkájukkal támogatják a közigazgatás múködését, a szakterület fejlődését, céljainak megvalósulását. Reméljük, hogy 2021-ben majd ismét lehetôség lesz a személyes találkozásokra, a szakmai eszmecserére a korábban megszokott körülmények között.

A földügyi szakterület szakmai irányítását az Agrárminisztériumban továbbra is a Földügyi és Térinformatikai Fôosztály végzi az Erdőkért és Földügyekért Felelôs Államtitkárság keretén belül, Zambó Péter államtitkár, Gyüre Anita földügyekért felelôs helyettes államtitkár vezetésével.

Annak ellenére, hogy 2020 a pandémia miatt várakozásainktól merôben eltérôen alakult, melynek okán új kihívásokkal is szembe kellett néznünk, mégis számos jelentôs feladatot sikerült megvalósítani a földügyi szakterületen. Az elmúlt év eredményei közül kiemelendô, hogy folytatódott a részarány-földkiadás során keletkezett osztatlan közös tulajdon megszüntetése tárgyú - közismert nevén OKTM - projekt, amelyben 2020 végéig összesen 36900 eljárás zárult le, ami az I-VI. ütemekben elindított 41000 eljáráshoz viszonyítva 90\%-os, a teljes projektet tekintve 69\%-os készültséget jelent. A lezárult eljárásokban mintegy 185 ezer tulajdonos részére került kiadásra az önálló tulajdonú földrészlet, hozzájárulva a tiszta tulajdoni viszonyok megteremtéséhez.

A 2020-as év bôvelkedett jogalkotási feladatokban, melynek során számos szakmai és funkcionális szabályváltozásra került sor, és amelyek által több, évtizedek óta megoldásra váró kérdés rendezése is megkezdődött.

Kiemelendô ezek közül a több mint két évtizede tartó, de máig lezáratlan részarány-földkiadási folyamat végleges rendezése, mely halaszthatatlan 
feladata volt a kormányzatnak a tiszta és egyértelmú tulajdonviszonyok kialakítása érdekében. Egyértelmúvé vált, hogy az eddigi jogszabályi rendelkezések nem tudják biztosítani a részaránytulajdon és a termelőszövetkezeti földhasználati jog idejétmúlt és az agrárium versenyképességét jelentôsen akadályozó jogintézményének a jogrendszerünkből való kivezetését, ezért a vonatkozó jogi szabályozás teljesen új alapokra helyezése, új szabályozási megoldások kidolgozása vált szükségessé. A lehetséges megoldások feltárása, valamint a leghatékonyabb intézkedéseket tartalmazó koncepció kidolgozása sokszereplôs egyeztetési folyamatot jelentett, melybe bevonásra kerültek az agrárium érintett képviselôi, valamint a feladat- és hatáskörük által érintett minisztériumok és egyéb állami szervek is.

Mindezek eredményeként született meg a termelöszövetkezeti földhasználati jog alatt álló földrészletek tulajdonjogának rendezésérôl és egyes földügyi tárgyú törvények módosításáról szóló 2020. évi XL. törvény, melynek elfogadásával belátható idôn belül a teljes részarány-földkiadási folyamat lezárhatóvá válik, az érintettek érdekeit messzemenôkig szem elôtt tartva.

A törvény rendelkezik azon, tulajdonjogilag rendezetlen jogállású földrészletek állami tulajdonba kerülésérôl, amelyek az ingatlan-nyilvántartás hatályos adatai szerint termelôszövetkezeti földhasználati jog alatt állnak, megteremtve ezzel a lehetőségét a szóban forgó ingatlanok jogszabályi elôírásoknak megfelelố hasznosításának.

A másik fontos rendelkezés, hogy a törvény biztosítja az érintett részarány-tulajdonosok megfelelô mértékú pénzbeli kártalanításának lehetôségét is. Ezzel kapcsolatban fontos kiemelni, hogy a jogosultakat megilletô részarány-tulajdon egy eszmei földtulajdon, amely kizárólag arra ad választ, hogy a termelőszövetkezetek által használt közös földekbôl ki milyen aranykorona értékú földnek a tulajdonosa. A részaránytulajdon tehát földrajzilag nem határozható meg, nem azonosítható egyetlen konkrét földrészlettel sem.

A több évtizedes tapasztalatok alapján a részarány-földkiadás jelentôs mértékben hozzájárult ahhoz, hogy mára az osztatlan közös földtulajdon rendkívül nagy arányban van jelen a magyar agráriumban, sok esetben önálló gazdálkodásra alkalmatlan, elaprózott tulajdoni hányadok formájában. A kormányzat kiemelt célja az osztatlan közös földtulajdon felszámolása, amellyel kapcsolatban önálló törvény is elfogadásra került. Mindezeket figyelembe véve nem támogatható, hogy újabb részarány-földkiadásokkal tovább fokozódjon az osztatlan közös földtulajdon problematikája. A 2020. évi XL. törvény ezért úgy rendelkezik, hogy a mai napig kiadatlan részaránytulajdonnal rendelkezó jogosultak a jövőben nem földre, hanem kizárólag pénzbeli kártalanítási összegre válthatják be részaránytulajdonukat. A kártalanítás aranykoronánkénti összegét a törvény a földek értékének országos alakulását figyelembe véve a korábbi 4000 forintról $50000 \mathrm{Ft}$ összegre emelte.

Figyelemmel arra, hogy a Kormány kiemelt célja a rendezetlen tulajdoni státuszú földrészletek helyzetének mielőbbi, végleges megoldása, ezért az új jogi szabályozás hatálya alól csak azok az esetek kerültek kivételre, ahol várható a folyamatban lévô részaránykiadási eljárás belátható idôn belüli lezárása. Ezek azok az esetek, amikor a mezógazdasági igazgatási szerv valamely földrészletet földkiadási határozattal, kérelemre induló eljárásban már tulajdonba adott, de a jogosult tulajdonjoga még nem került az ingatlan-nyilvántartásba bejegyzésre, vagy valamely földrészletet nyilvános sorsolás útján történố tulajdonba adás céljából sorsolási hirdetményben már közzétett, illetve a kárpótlási célú árverezés érdekében a kárpótlási hatóság meghirdetett.

A jogosultak kártalanítás iránti kérelmükkel az ingatlanügyi hatóságként eljáró kormányhivatalokhoz fordulhatnak, a kártalanítási eljárás részleteit a termelôszövetkezeti földhasználati jog alatt álló ingatlanok állami tulajdonba kerülésével kapcsolatban a részaránytulajdonosok kártalanításának szabályairól szóló 560/2020. (XII. 7.) kormányrendelet tartalmazza.

Kiemelkedô fontosságú jogalkotási feladat volt továbbá a földeken fennálló osztatlan közös tulajdon felszámolásáról és a földnek minósülố ingatlanok jogosultjai adatainak ingatlan-nyilvántartási rendezésérôl szóló 2020. évi LXXI. törvény megalkotása. A törvényhez kapcsolódó részletszabályokat a földeken fennálló osztatlan közös tulajdon felszámolásának részletes szabályairól szóló 647/2020. (XII. 23.) kormányrendelet tartalmazza.

A törvény legfőbb célja a tiszta, átlátható földtulajdoni struktúra kialakítása és az ennek egyik legnagyobb akadályát képezô osztatlan közös földtulajdon mint kényszerközösség hatékony felszámolása.

A 2019. év végi adatok szerint hazánkban mintegy 1 millió 60 ezer földrészlet áll osztatlan közös tulajdonban. A jelenlegi OKTM-projekt sok tekintetben elôsegítette a földeken fennálló osztatlan közös tulajdon felszámolását. Ezen eljárás hátránya ugyanakkor, hogy meglehetôsen hoszszadalmasnak bizonyul, és csak részben oldja meg a problémát, hiszen a megosztás lehetôsége nem terjed ki az összes osztatlan közös tulajdonú földre, valamint a maradványingatlanok tekintetében továbbra is fennmarad a kényszerközösség.

A fentiekból egyértelmúen következik, hogy az átlátható földtulajdoni struktúra kialakítása érdekében szükséges az osztatlan közös tulajdon felszámolására irányuló intézkedések folytatása, de a folytatáshoz elengedhetetlen az osztatlan közös tulajdon megszüntetésére irányuló eljárás új alapokra helyezése.

Általánosságban véve elmondható, hogy a törvény célja minden esetben a felek egyezségének támogatása, a tulajdonrészek minél nagyobb számban történố önálló ingatlanná alakítása, valamint a tényleges földhasználók további tulajdonszerzésének ösztönzése, és mindezek által jól hasznosítható birtoktestek kialakítása egy a jelenleginél jelentősen rövidebb folyamat keretében. Jelentôs változás továbbá, hogy a törvény hatálya eltérốn az OKTM-eljárásoktól - nem csak a részaránykiadás útján, hanem bármely jogcímen keletkezett osztatlan közös tulajdonra, valamint az erdőnek minôsülố ingatlanokra is kiterjed. 
A megosztási folyamat zavartalan lebonyolítását elôsegítendô a jogszabály 90 napos változtatási tilalmat vezet be, amely idôtartam alatt az ingatlan tulajdoni lapján - az öröklést és a kisajátítást kivéve - semmilyen változtatás nem vezethetố át: sem az ingatlan adataiban, sem az ingatlant érintô jogokban és tényekben. Ez az idôtartam a tulajdonostársak kezdeményezésére, a folyamatban lévô megosztás tényének ingatlan-nyilvántartási feljegyzésével indul. Amennyiben a 90 napos időtartam eredménytelenül telik el, azt követốen 30 napon belül újabb változtatási tilalom nem kezdeményezhetô.

A jogi megoldás megújítása mellett a tulajdonostársak egy kifejezetten e célt szolgáló informatikai program, az úgynevezett osztóprogram alkalmazásával maguk készítik el azt a térképvázlatot, amely a megállapodásuk szerinti megosztás térképi megjelenítését szolgálja. Ez az osztóprogram hozzáféréssel rendelkezik majd az ingatlan-nyilvántartás aktuális térképi és tulajdoni lapi adataihoz. A birtokelaprózódás megakadályozása kiemelt cél, ezért a megosztással létrejövố új ingatlanok tekintetében a törvény területi minimumot állapít meg. A jelenleg folyamatban lévố OKTM-eljárásokkal ellentétben, az új eljárásban a területi minimumot el nem érô, azaz az önálló ingatlanná nem alakítható tulajdoni hányadok nem maradnak közös tulajdonban. Azokat valamelyik tulajdonostárs köteles magához váltani, és értük legalább az ingatlan-értékbecslés szerinti értékének megfelelő ellenértéket megfizetni. A területi minimumot el nem érô tulajdoni hányadok jogosultjai ezáltal valós kompenzációban részesülnek.

A törvény a birtokrendezésre is lehetôséget biztosít egyrészt azáltal, hogy az egyezségben az eredeti tulajdoni hányadoktól eltérô megosztásban is meg lehet állapodni, így a gyakorlatban a tulajdonostársak között földszerzésre is sor kerülhet. Emellett ugyanazon tulajdonostársak több - azonos, vagy egymással szomszédos település közigazgatási területéhez tartozó ingatlan megosztása során megállapodhatnak abban is, hogy az egyes tulajdonostársak több ingatlanban fennálló tulajdoni hányadai egy ingatlanként kerüljenek kijelölésre.
A törvény az osztatlan közös tulajdon megszüntetésére a megosztáson túl kínál egy második megoldási lehetôséget is. Erre azért van szükség, mert vannak olyan ingatlanok, amelyekból térmértékük alapján - eleve nem alakítható ki legalább két, a területi minimumot elérố ingatlan, így esetükben a megosztás szóba sem jöhet. Ezen ingatlanok vonatkozásában az osztatlan közös tulajdon megszüntetésére az egyetlen lehetôség az, ha az ingatlan teljes egészében az egyik tulajdonos tulajdonába kerül, legalább az ingatlan értékbecslés szerinti értékének megfelelố ellenértékért.

Ahol sem a tulajdonosi egyezség, sem a tulajdonostárs általi pénzbeli megváltás nem lehetséges, az osztatlan közös tulajdon megszüntetésének legvégsố megoldása az lehet, ha ezek az ingatlanok - a megosztás sikertelensége esetén, valamely tulajdonostárs kezdeményezésére - kisajátítás útján a Magyar Állam tulajdonába kerülnek. A tulajdonostársak a tulajdonrészükért megfelelő pénzbeli ellentételezést kapnak, a Magyar Állam pedig gondoskodni tud az immáron kizárólagos állami tulajdonban lévô ingatlan megfelelố hasznosításáról.

Sokan szembesültek már azzal a helyzettel, hogy a tulajdoni lapon szereplố tulajdonostársak közül többen elérhetetlenek, vagy gyaníthatóan már nem is élnek, és hagyatéki eljárásban sem rendezték az ingatlan jogi sorsát. Ez a bizonytalan tulajdonosi helyzet nem csak az osztatlan közös tulajdon megszüntetése, hanem az ingatlanok megfelelô hasznosítása során is nehézséget jelent. Mindezek okán a törvény egy új eljárás bevezetésével kísérletet tesz a földnek minôsüló ingatlanok tekintetében a tulajdonosként az ingatlan-nyilvántartásba bejegyzett azon személyek beazonosítására, akiknek az ingatlan-nyilvántartásban szereplố adatai hiányosak. Az eljárás keretében a törvény az ingatlanügyi hatóság számára hivatalból történô kötelezó adatfeltárást, adategyeztetést és annak sikeressége esetén adatkiigazítást ír elő. Kötelező adatfeltárást és adategyeztetést szükséges végezni abban az esetben is, ha az ingatlan-nyilvántartásba tulajdonosként bejegyzett személy 120 évnél idősebb, és e személy halálának idốpontjára vonatkozóan hiteles adat nem áll rendelkezésre. A rendezetlen tulajdoni helyzetû ingatlanok mindkét esetben a törvény erejénél fogva az állam tulajdonába kerülnek. Ezzel az eljárással a jogszabály megteremti a lehetôségét a földek hasznosítását akadályozó és az ingatlan-nyilvántartás teljességének elvét gyengítô bizonytalan tulajdonosi helyzetek rendezésének.

Mindezek alapján lehetôvé válik az osztatlan közös tulajdonnal érintett mintegy 2,4 millió hektár föld jogi sorsának egységes elvek mentén, a jelenleginél sokkal gyorsabb eljárások keretében, az állam minimális szerepvállalása mellett történő rendezése.

A Földmérési és Térinformatikai Fốosztály a megváltozott körülmények ellenére - a korábbi évekhez hasonlóan - 2020-ban is folyamatosan tájékoztatást adott az aktuális feladatok alakulásáról a szakmai rendezvényeken, fórumokon, amelyek közül kiemelendô az évek óta nagy létszámú érdeklôdô részvételével, az MFTTT-vel közösen megrendezésre kerülő osztatlan közös tulajdon megszüntetésérôl szóló konferencia és továbbképzés. Erre a rendezvényre az idei év során is nagy hangsúlyt kívánunk fektetni, különös tekintettel az elinduló új eljárásra. Reményeink szerint a járványügyi helyzet lehetôvé teszi majd, hogy ne az online térben, hanem személyes találkozó keretében kerüljön sor erre a mindig nagy érdeklődésre számot tartó konferenciára 2021-ben.

\section{Tisztelt Kollégák!}

Az Ingatlan-nyilvántartási és Térképészeti Fôosztály (ITF) irányításában is változással kezdôdött az év. A területi közigazgatásért felelôs államtitkár személye megváltozott, így 2020. január 1-jétől dr. György István államtitkár látja el a feladatot, az ITF munkájának közvetlen irányítása pedig dr. Almási Gyôzô hatósági ügyekért felelős helyettes államtitkár feladata lett.

Az év elsố negyede a fốosztályon az ingatlanügyi hatóságokként eljáró fôvárosi és megyei kormányhivatalok március 1-jével történô átalakításra való felkészítése jegyében telt. Ez nemcsak az ekkor szükséges kodifikációt jelenti, hanem a hatóságok munkáját segítő 
eljárásrendek, módszertani útmutatók elkészítésérôl és az átalakulás szakmai koordinációjáról is szól. Az átalakítás sikeres végrehajtásában kiemelt szerepet játszott a földmérési és térinformatikai államigazgatási szerv feladatait ellátó Lechner Nonprofit Kft. és munkatársainak kiváló feladatellátása.

$\mathrm{Az}$ ingatlanügyi hatóságok munkája az átalakítással nagymértékben - az ügyfelek számára is érzékelhetô módon - megváltozott. A legfontosabb vívmány, hogy a fellebbezés mint jogintézmény megszûnt, az ingatlan-nyilvántartási és telekalakítási eljárások egyfokúvá váltak, így az azokban hozott döntések ellen csak bírósági eljárással lehet élni. Az egyfokú eljárások intézése a járási hivatalokból a fôvárosi és megyei kormányhivatalokba tevôdött át. Ennek elônye, hogy az ügyteherelosztás megyén belül sokkal rugalmasabb lehet, ami összességében az egységes megyei leterheltség révén az ügyintézési határidô csökkenését jelenti. Feltétlenül meg kell említenem, hogy az ingatlanügyi hatósági feladatokat ellátó kormánytisztviselôk bérrendezése, a rendelkezésre álló státuszok felülvizsgálata és feltöltése révén az ügyintézési határidők az egész országban csökkentek.

A második negyedévben - az építésügyi hatóságok szakmai irányítását ellátó helyettes államtitkársággal való szoros együttmúködés eredményeként - hatályba léptek azok a kormány- és miniszteri rendeletek, melyek révén az egyes épületek, egyéb önálló ingatlanok rendeltetésének meghatározása, ingatlan-nyilvántartási átvezetése rendezettebbé vált. Az ôsz folyamán - az ingatlan-nyilvántartási szempontból is prioritást élvezô szempontok figyelembe vétele mellett - ezen rendelkezéseket módosították, így elmondható, hogy egy-egy ingatlan fó rendeltetési jellegének megváltoztatása, meghatározásának szabályai zárt rendszert alkotnak.

A második negyedévben lépett hatályba az - immár a Miniszterelnökség hatáskörébe tartozó - ingatlan-nyilvántartási célú földmérési és térképészeti tevékenység részletes szabályairól szóló 8/2018. (VI. 29.) AM-rendelet módosítása is, amely mind a vonatkozó eljárásokra, mind pedig a szakmagyakorlásra egyszerúsítő, egyértelmúsítő szabályokat hozott.

A 2020-as év a világjárványról szólt, ami természetesen érintette az ingatlanügyi hatóságok, valamint a szakmai irányító Miniszterelnökség munkáját is. A pandémia azonban közvetlen és súlyos kihatással nem volt az ingatlanforgalomra, ezáltal pedig az ingatlanügyi hatóságok munkájára sem. Ugyanakkor a digitalizáció, az elektronikus ügyintézés bevezetése az eddigieknél nagyobb hangsúllyal jelent meg. Az elektronikus beadvány benyújtására a lehetôség már adott: beszédes szám, hogy 2020 elsố tíz hónapjában az ingatlanügyi hatósághoz beérkezett kérelmek harmadát elektronikusan nyújtották be az ügyfelek.

Annak érdekében, hogy a tényleges, valamennyi elektronikus ügyintézési szegmenst (tehát többek között a papírmentes ügyintézést a back office tevékenységek során, az elektronikus döntés meghozatalát és kézbesítését, a más nyilvántartásokkal történô online, automatikus kapcsolattartást) magába foglaló földügyi igazgatási eljárások lefolytathatók legyenek, az e-ingatlannyilvántartás KÖFOP-projekt végrehajtására a Területi Közigazgatásért Felelôs Államtitkárság kiemelt figyelmet fordít.

A projekt megvalósításához szükséges feladatok végrehajtásában az ITF aktív szerepet vállal, mely meghatározza a 2021-es év tevékenységeit is. A projekt során létrejövố új informatikai rendszer bevezetéséhez szükséges jogszabály-módosítások, a térbeli térképi nyilvántartás bevezetése, a hatósági eljárások, az adatszolgáltatások felülvizsgálata jelentôs feladatot ró a fốosztályra, amely a Lechner Tudásközponttal szorosan együttmúködve végzi ezirányú tevékenységét.

Mindemellett, a Nemzeti Kataszteri Program Nkft. jogutódlásával járó gazdasági és kodifikációs feladatok 2020 negyedik negyedévében értek véget. Erre tekintettel prioritást élvezhet a szükséges infrastrukturális és pénzügyi erôforrások, kompetenciák megteremtése, és a térképi állományok javítása, felújítása, mely több szempontból is fontos tényezô. Természetesen általános és jogos elvárás, hogy az ország alaptérképei minél pontosabbak legyenek. Emellett azonban az e-ingatlan-nyilvántartás megvalósítása, valamint az Agrárminisztérium által koordinált - de az ingatlan-nyilvántartásra értelemszerúen kiható földnek minôsülố ingatlanok osztatlan közös tulajdon megszüntetésére irányuló kormányzati törekvések miatt is elsôdleges a térképi állományok megfelelôsége. A térképfelújítások esetében többirányú feladatok is megmutatkoznak, amelyek az ITF 2021. évi munkájának fontos részét képezik. . Egyrészt elengedhetetlen a feladat pénzügyi tervezésében való részvétel, illetve ennek jóváhagyása, emellett folyik az esetlegesen kihasználható új technológiák (távérzékelés, ezen belül is a dróntechnológia) alkalmazásának vizsgálata, illetve a vonatkozó jogszabályi környezet felülvizsgálata.

\section{Kedves Kollégáink és Tagtársaink!}

A Magyar Földmérési, Térképészeti és Távérzékelési Társaság tevékenységére ez évben rányomta bélyegét a Covid-19 koronavírus okozta világjárvány (pandémia) hazánkat is sújtó elsô és második hulláma, és nem tudjuk, hogy 2021-ben mikor fog normalizálódni a helyzet. Mégis most az új év elején nagy reményekkel és új tervekkel tekintünk a 2021. évre.

Az MFTTT életében a 2020. esztendô egészében véve, a borzasztó körülmények között is eredményes volt. A nehézségek ellenére a Társaság pénzügyi egyensúlyát meg tudtuk teremteni, és a múködőképességét folyamatosan biztosítottuk. Az ehhez szükséges anyagi forrást egyrészt a év folyamán befolyt egyéni és jogi tagdíjak, a Geodézia és Kartográfia (GK) előfizetési díjai, a GK-ban megjelent hirdetések díjai, másrészt a sikeres pályázati tevékenységeinkből befolyó támogatás, továbbá néhány ôszi nagyrendezvényünk eredményei, valamint a Budapesti és Pest Megyei Mérnöki Kamarával (BPMK) korábban kötött együttmúködési megállapodásunk keretében a BPMK-tól a GK nyomdai költségeinek részbeni fedezetére kapott támogatás tették lehetôvé.

Jól ismert, hogy Társaságunk egyedüliként képviseli hazánkat három 
szakmai világszervezetben, nevezetesen a Földmérôk Nemzetközi Szövetségében (FIG), a Nemzetközi Térképészeti Szövetségben (ICA) és a Nemzetközi Fotogrammetriai és Távérzékelési Társaságban (ISPRS). A másik két hazai szervezettel, nevezetesen a Magyar Földmérô és Geoinformatikai Vállalkozások Egyesületével (MFGVE) és a Magyar Mérnöki Kamarával (MMK), illetve az MMK Geodéziai és Geoinformatikai Tagozatával (MMK-GGT) együtt komoly a szerepvállalásunk az Európai Földmérôk Tanácsában (CLGE) is. Mivel kérésünket dr. Nagy István miniszter úr az AM részérôl 1300000 Ft-al támogatta, így be tudtuk fizetni a nemzetközi szakmai szervezeteknek a 2020. évi tagdíjunkat. Társaságunk képviseltette magát az ICA vezetôségi ülésein, köszönhetôen annak, hogy a szervezet egyik jelenlegi alelnöke $d r$. Zentai László egyetemi tanár, az ELTE Térképtudományi és Geoinformatikai Intézetének vezetôje. A többi nemzetközi szervezettel (CLGE, FIG, ISPRS) nemzeti képviselôink online formában tartották a kapcsolatot.

Társaságunk nemzetközi tevékenységéhez szorosan kapcsolódik az intézóbizottság (IB) által korábban létrehozott MFTTT-WG4SDG munkabizottság (elnöke: $d r$. Mihály Szabolcs, tagjai: Hargitai Péter, Iván Gyula, RemeteyFülöpp Gábor, Palya Tamás és $d r$. Zentai László) múködése. Aktívan képviselik Társaságunkat előadásokkal és tanulmányok készítésével az ENSZ Fenntartható Fejlődési Célok elérésének szolgálatában megjelenô térinformatikai és földmegfigyelési feladatok terén. A munkájuk eredményeként megjelent publikációk és előadási anyagok elérhetôk az MFTTT honlapján, elkülönített menüpontban.

Társaságunk - az Alapszabályával összhangban - folytatta (ez évben sajnos csak korlátozottan) együttmúködését az Erdélyi Magyar Múszaki Tudományos Társaság (EMT) Földmérô Szakosztályával (FSz). Az EMT FSz által tervezett XXI. Földmérô-találkozó (Székelyudvarhely, 2020. május 21-24.) a világjárvány miatt elmaradt, és ennek okán maradt el az EMT alapításának 30. évfordulója alkalmából tervezett emlékülés is (Marosvásárhely, 2020. március
14-15.). Ennek ellenére vezetői szinten tartottuk a kapcsolatot, továbbá a két szervezet (EMT és MFTTT) együttmúködése keretében, a székely származású Márton Gyárfás professzor emlékére alapított közös szakmai emlékplakettet 2020-ban már nyolcadik alkalommal ítéltük oda (Márton Edith, csíkszeredai földmérômérnök kolléganô és $d r$. Mihály Szabolcs tagtársunk részére). A kitüntetést várhatóan 2021-ben valamelyik, már jelenléti formában tartandó rendezvény keretében (az EMT FSz XXI. Földmérő-találkozóján és/vagy az MFTTT 33. Vándorgyúlésén) fogjuk átadni.

Szakosztályaink és területi csoportjaink többsége a lehetôségekhez mérten tudott csak múködni. A „Zalai Geodétatalálkozó” (Sormás, 2020. szeptember 22.) kivételével sajnos elmaradtak a területi csoportjaink hagyományosan eredményes és sikeres földmérônapi rendezvényei is. Többnyire megyei szinten, a kormányhivatalok a megyei és járási földhivatalok szakemberei számára rendeztek zártkörûen (kis létszámú részvétellel) továbbképzô jellegú találkozókat (pl. a Nógrád megyei földmérôk a Tar községhez tartozó Meggyespusztán tartottak ilyen rendezvényt 2020. június hónapban). Figyelemre méltó továbbá, hogy Társaságunk Vas Megyei Területi Csoportja Bolla Attila és Nagy István tagtársak szervezésében a Nemzeti Összetartozás Napjához kapcsolódóan, 2020. június 30-án baráti-szakmai összejövetelt rendeztek a horvátzsidányi Péruska Máriaemlékparkban. A találkozó keretében megkoszorúzták a földmérôk védôszentjeként számontartott Szent Tamás szobrát, amelyen Társaságunk is képviseltette magát.

Társaságunk folyamatos múködtetése céljából az elmúlt év során négy IB- és két választmányi ülést tartottunk, továbbá két alkalommal hívtuk össze a közgyúlést (mindegyiket online formában). A testületi üléseinken hozott fontosabb döntéseinket határozatokba foglaltuk. 2020-ban összesen 12 IB-határozatot, 5 választmányi és 8 közgyúlési határozatot hoztunk, amelyek a Társaságunk honlapján elérhetôk, illetve a Titkárságon tanulmányozhatók. A Társaság 2020. évi Lázár deák emlékérmét választmányunk ifj. Domokos György tagtársunknak itélte oda, melyet a Társaságunk 2021. évi nagyobb nyilvános, már jelenléti formában tartandó rendezvényén (közgyúlés vagy vándorgyúlés) keretében fogjuk átadni.

Az Alapszabályunkat nem módosítottuk, bár kisebb változtatását a teljes körú tartalmi összhang elérése (az apróbb ellentmondások megszüntetése) és a szakosztályok szakmai szempontú átalakítása továbbra is indokolja a közeli jövôben. Erre a feladatra az év elején egy ad hoc bizottságot kértünk fel, amelynek vezetôje Horváth Gábor István, tagjai pedig Busics Imre, dr. Csevár Nóra, Koós Tamás, dr. Kovács Miklós és Várnay György tagtársak.

Testületi üléseinkre a felügyelôbizottság elnökét és tagjait mindig meghívtuk, akik közül egy-egy fố rendszerint részt is vett azokon. Konstruktív észrevételeikkel nagyban segítették a Társaság múködtetését.

Társaságunkat 2020. év elején felkérték a Miniszterelnökség Hatósági Ügyekért Felelôs Helyettes Államtitkárságának Ingatlannyilvántartási és Térképészeti Fôosztálya részérôl a fốosztály kormányrendeletekre és miniszteri rendeletekre vonatkozó jogszabály-módosítási javaslatainak véleményezésére, melyet Horváth Gábor István fótitkárhelyettes vezetésével végeztünk el.

Képviseltettük a Társaságunkat - többek között - a Magyar Katonai Térképészet Napján (február 3-án), a 2019. évi Eötvös Loránd (1848-1919) emlékévet szervezô bizottság záróülésein stb.

Az Európai Földmérôk Tanácsa (CLGE) a földmérômérnöki foglalkozás és a földmérôk által végzett fontos tevékenység megbecsülése és a köznyilvánosság elôtti elismertetése céljából 2020-ban március 21-ét (immár kilencedik alkalommal) az „Európai Földmérôk és Geoinformatikusok Napjává” nyilvánította. Március 21-ét a FIG kezdeményezése és döntése alapján a Földmérők Világnapjává (Global Surveyors Day) is nyilvánították, amelyet most már harmadik alkalommal világszerte megünnepeltek. A rendezvénysorozathoz egész napos konferenciával (EFGN2020) kívántunk 
kapcsolódni, melynek szakmai programját az MFTTT szervezte Iván Gyula fôtitkárhelyettes vezetésével a CLGEben a magyarországi földmérôket és térképészeket képviselô másik két szervezettel (MFGVE és az MMK-GGT) együttmúködésben. A rendezvényt eredetileg 2020. március 19-re terveztük, de a koronavírus-világjárvány miatt ôszre halasztottuk, és 2020. november 18-án rendeztünk meg online formában. A konferencia védnöke $d r$. Nagy István agrárminiszter volt. Az elôadásokat szakterületünk meghatározó állami, katonai, vállalati és oktatási intézményeibốl választottuk. Összesen 15 színvonalas elôadást hallottunk. A résztvevốk száma végig 100 fố körül volt. Az említett két rendezvényt az Emberi Erôforrás Támogatáskezelô Nemzeti Kulturális Alapja (NKA) is támogatta (nyertes pályázatunknak köszönhetôen, $500000 \mathrm{Ft}$-al).

Az ôszi nagyrendezvényünket az Agrárminisztérium (AM) Földügyi és Térinformatikai Fốosztályával és az AM Nemzeti Földügyi Központja Birtokpolitikai Fôosztályával (a Nemzeti Kataszteri Program Nonprofit Kft. jogutódintézményével) együttesen az „Osztatlan közös tulajdon megszüntetésének szabályairól szóló 374/2014. (XII. 31.) kormányrendelet végrehajtásához kapcsolódó továbbképzés és fórum" címú témakörben (OKTM2020) 2020. november 11-én online formában szerveztük meg dr. Toronyi Bence alelnök vezetésével. Felkérésünkre dr. Nagy István agrárminiszter úr elvállalta a konferencia fôvédnökségét. A nagy érdeklődésnek köszönhetôen a rendezvényen mintegy 150 fố vett részt.

Folytattuk Társaságunk tavaszi és az ôszi-téli szakmai elôadássorozatának lebonyolítását továbbképzési jelleggel (eléggé korlátozott mértékben). Az elôadások egy részét kihelyezett helyszíneken (pl. a BME Általánosés Felsôgeodézia Tanszékén a Rédey István Geodéziai Szeminárium keretében) online formában tartottuk meg.

Köszönjük, hogy 2020-ban is Társaságunk tagjai maradtak, fizették a tagdíjat, és ezzel is segítették munkánkat. Az IB javaslata és a választmányunk megállapítása alapján a Társaságunk közgyúlésének 2020. december 17-ei döntése alapján, a 2021. évi tagdíjak az elôzó évhez képest nem változtak. Ennek értelmében az aktív dolgozók esetében a tagdíj 10000 Ft. Diákok, egyetemi hallgatók és nyugdíjasok számára változatlanul 5000 Ft (lap nélkül $1000 \mathrm{Ft}$ ). A GK szakmai folyóiratunk előfizetési díja nem MFTTT tagok és közületek részére továbbra is $18000 \mathrm{Ft}+$ áfa. A jogi tagdíjak összege sem változott. Az egyéni tagjainknak teljes körú hozzáférést biztosítunk a honlapunkhoz (www.mfttt.hu), és természetesen - a tagdíj befizetése ellenében - rendszeresen kapják a szakmai folyóiratunkat. Továbbá Társaságunk tagjai az MFTTT rendezvényein alacsonyabb részvételi díjat fizetnek.

Köszönettel tartozunk mindazoknak még, akik anyagilag is támogatták Társaságunkat. Igen sok magánszemély tisztelt meg bizalmával és szerény adománnyal, az állami intézmények közül pedig kiemelt köszönet illeti az Agrárminisztérium támogatását, de nem múködhetne titkárságunk a Budapest Fốváros Kormányhivatala (BFKH), illetve a Lechner Tudásközpont (LNK) által biztosított infrastruktúra nélkül sem. Kiemelt segítséget kaptunk az MH Geoinformációs Szolgálattól is. Köszönettel tartozunk dr. Rózsa Szabolcs egyetemi docensnek, a BME Általános- és Felsôgeodézia Tanszék tanszékvezetôjének az egyetem MS Teams felületének rendelkezésünkre bocsátásáért, amely a rendezvényeink (OKTM2020, EFGN2020 és decemberi testületi üléseink) online térben történô megszervezésének szoftveres hátterét biztosította. Köszönjük Szrogh Gabriella ügyvezetố titkárnak és Horváth Zoltánnak, hogy megtanulták a Nextcloud társalgási szoftver használatát, és azt sikerrel tudtuk használni (a szeptemberi testületi üléseink és a Zalai Geodétanap online formában történô lebonyolításában).

Társaságunk alapvetô céljai és feladatai között szerepel a szakmatörténeti hagyományok ápolása. Ehhez kapcsolódóan Társaságunk 2017. ben IB-határozatban támogatta, hogy Magyarország csatlakozzon az osztrák társszervezet kezdeményezéséhez, „A határok és határjelek hálózatának Világörökség részévé nyilvánítása” elnevezésû́ UNESCO-projektben való részvételünket. Az MFTTT részérôl kezdeményeztük a Budapest Fôváros Kormányhivatalánál, hogy a szükséges dokumentumokat és teendôket a BFKH korábbi Földmérési, Távérzékelési és Földhivatali Fôosztálya készítse és lássa el. Ezt dr. György István akkori kormánymegbízott engedélyezte, és aláirta a részvételrôl szóló szándéknyilatkozatot, amelyet a Társaság részérôl az elnök is ellátott kézjegyével és ezt kiküldtük a projektet koordináló osztrák fél részére. A projektben összesen 8 közép-európai ország vesz részt (Ausztria, Cseh Köztársaság, Horvátország, Lengyelország, Magyarország, Szlovákia és Szlovénia). A projekt megvalósításában lényeges előrelépés történt 2020. második felében, mert Peter Waldhausl professor emeritus vezetésével elkészült egy 168 oldalból álló dokumentum, melynek címe: The Network of Boundaries and its Monuments - Thematical Study and proposed Nomination Strategy for World Heritage (A határjelek hálózata és múemlékei - Tematikus tanulmány és javasolt jelölési stratégia a Világörökség számára). Ez már tartalmazza a Magyarország részérôl javasolt négy (múemlék jellegú) pont (Gellérthegyi vetületi kezdôpont, Nadapi szintezési fóalappont (ősjegy), magyar-osztrák-szlovén hármashatárjel és a magyar-osztrák határjel a Fertô-tóban) leírását a szükséges dokumentumokkal együtt. Az eljárás folytatódik, így 2021-ben is lesznek feladataink ezzel kapcsolatban.

Dr. Györffy János tagtársunk kérésére az MFTTT vezetésének egyetértésével hozzájárultunk ahhoz, hogy édesapja Györffy György neves történész akadémikus emléktábláján a Társaságunk neve is szerepeljen. Györffy György (1917-2000) a magyar őstörténet és az Árpád-kor kutatója volt, aki nem csak használta a térképeket a kutatásaihoz, de számos térképet szerkesztett, és jelentôs szerepe volt a középiskolai történelmi atlasz szerkesztésében is. Másik szakmai kapcsolódása az, hogy a II. világháború alatt a Honvéd Térképészeti Intézetben is dolgozott. Az emléktáblát 2020. december 20-án leplezték le a Múzeum krt. 15. számú házának falán, amelyben 61 évig élt. 
A Jászfényszarun működő Bedekovich Lốrinc Népfôiiskolai Társaság elnökének felkérésére támogató ajánlást készítettünk pályázatukhoz, amely szerint az „idôsebb komori Bedekovich Lôrinc a Jászkun kerület elsố földmérố és vizépitô mérnök munkássága" megnevezéssel Bedekovich Lôrinc (1751-1823) kiemelkedố mérnöki tevékenysége nemzeti értékként kerüljön felvételre a Nemzeti Értéktárba. Id. Bedekovich Lórinc egyik kiemelkedố képviselôje azoknak a gyakorló földmérôknek, hites vármegyei mérnököknek és matematikusoknak a 18-19. századforduló idején, akik a központilag szervezett állami felmérés idôpontját megelőzốn a magyar térképészet és felmérés ügyét szolgálták.

A 2021. év elé nagy várakozással tekintünk, és terveink szerint ez is mozgalmasnak ígérkezik az MFTTT életében. Néhány kiemelt feladatunk: a Társaság pénzügyi egyensúlyának fenntartása, melyet alapvetôen a taglétszám megtartásával, illetve lehetôség szerint emelésével, továbbá eredményes pályázati tevékenységgel, valamint a társszervezetekkel és szakmai intézményekkel, szakmai foohatóságainkkal történő kapcsolatok erôsítésével remélünk biztosítani. Fontosnak tartjuk az MFTTT taglétszámának emelését. Jelenleg 532 fő egyéni regisztrált és 32 jogi tagunk van. Az egyéni taglétszámmal nem lehetünk elégedettek, annál is inkább, mert tudomásunk szerint az MMK-GGT keretében valamivel több, mint 1100 regisztrált földmérố kamarai tagot tartanak nyilván. Sajnos a fiatal szaktársainkat nehéz megnyerni a társasági (közéletitársadalmi) munkára.

Szeretnénk elérni, hogy a nemzetközi szervezeteknek a 2021. évi tagdíjat is be tudjuk fizetni. (Ebbôl a célból az év folyamán levélben fordulunk a szakmai főhatóságunk egyik vezetôjéhez, dr. Nagy István agrárminiszterhez, hogy az Agrárminisztérium nyújtson támogatást az MFTTT részére.) Fontos célkitǔzésünk az Európai Földmérôk és Geoinformatikusok Napja és a Földmérôk Világnapja (EFGN2021, 2021. március 18-án), valamint az ôszi szakmai nagyrendezvényünk eredményes és sikeres megszervezése és lebonyolítása (a tavalyi témakörben: az „Osztatlan közös tulajdon megszüntetésének szabályairól szóló 374/2014. (XII. 31.) kormányrendelet végrehajtásához kapcsolódó továbbképzés és fórum") (OKTM2021), továbbá az EMT FSz XXI. Földmérôtalálkozón (Székelyudvarhely, 2021. májusban, esetleg ôsszel) sikeres szereplés. Az EFGN2021 rendezvényének eredményes és sikeres lebonyolításához pályázat alapján 500000 Ft támogatásban részesülünk.

Itt jegyezzük meg, hogy 2012 óta az EFGN elôadóülése keretében a szakmánk szempontjából kiemelkedô személyekrốl, a múltban végzett földmérési/geodéziai/matematikai munkálatról is megemlékezünk, az egyes országok előterjesztésére, a CLGE általános közgyúlésének jóváhagyása alapján. Németország elôterjesztésére idén Karl Friedrich Gauss (1777-1855) lesz az ünnepelt európai földmérô (The European Surveyor of the Year 2021).

2021-ben egyik kiemelkedố fontosságú feladatunk lesz az MFTTT soron következő, 33. Vándorgyưlésének eredményes megszervezése és sikeres lebonyolítása. Helyszínérôl és idôpontjáról már 2019-ben, az IB egyik ószi ülésén döntöttünk, mivel szerettük volna már 2020. július 7-9. között megtartani, de ezt is el kellett halasztanunk egy évvel (Miskolc, 2021. június 24-26). A helyi szervezóbizottság elnöki feladatainak ellátására Plesovszki Adrienn tagtársat kértük fel.

Feltétlenül szükséges a Társaság múködôképességének további fenntartása, a GK szakmai folyóiratunk színvonalas megjelentetésének biztosítása, az egyre népszerúbbé váló honlapunk folyamatos múködtetése és feltöltése a Társaságunkra vonatkozó idôszerú ismeretekkel. Fontos fejlemény, hogy a Geodézia és Kartográfia 2017 novemberétôl újra indexálásra került a Scopus adatbázisban, továbbá a megjelent publikációk digitális azonosítót kapnak, és bekerülnek az ELTE Digitális Tudástárába (EDIT) is. 2019-ben pedig a GK eddig megjelent valamennyi lapszámának elkészült a szkennelése és digitális publikálása az Arcanum Adatbázis Kft.-vel együttmúködésben. Erre vonatkozóan a kiadói jogokat gyakorló MFTTT és az Arcanum Adatbázis Kft. szerzôdést kötött még 2019-ben.
Biztosítjuk a testületi ülések (a körülmények alakulásától függôen hat-nyolc intézôbizottsági és háromnégy választmányi ülés, valamint kéthárom közgyúlés) lebonyolítását. Az elsô közgyưlést 2021. május végén fogjuk tartani.

Társaságunk 2021-ben is nagy hangsúlyt fektet olyan akkreditált, továbbképzés-jellegú konferenciák szervezésére, melyekkel lehetôséget teremtünk tagjaink számára arra, hogy megszerezzék a szakmájuk gyakorlásához előírt kreditpontokat.

Képviseltük Társaságunkat a Földtudományi Civil Szervezetek Közösségének (FöCiK) rendezvényein. A FöCiK jelenleg kilenc, korábban a MTESZ keretei között múködô, földtudományi szakmai civil szervezetet foglal magában a 2014. június 24-én aláirt együttmúködési megállapodás értelmében. Társaságunk eddig öt alkalommal vett részt (2015-2019) önálló kiállítással a „Földtudományos Forgatag” rendezvényen. 2020-ban ez a rendezvény a világjárvány miatt sajnos elmaradt, de 2021-ben reméljük már ott lehetünk ezen a rendezvényen (2021. november 6-7-én). A FöCiK legutóbbi ülésén (2020. december 12-én) választottuk meg a szervezet hetedik elnökét, $d r$. Zelei Gábor személyében, aki az előzô elnök is volt (az MGE elnökeként), most pedig az OMBKE képviseletében, mivel 2020. november 1. óta a szervezet ügyvezetố igazgatója.

A FöCiK tagegyesületei elhatározták, hogy 2019-2020 folyamán saját erôforrásaikra támaszkodva hozzá kívánnak járulni a középiskolák természettudományos tantárgyai súlyának növeléséhez, a földtudományok oktatásának javítása érdekében. A FöCiK tagszervei nagyon jól lefedik azokat a szakterületeket, amelyek a természettudományok iránt nyitott diákok érdeklődésére számíthatnak. A Közösség 2020 második félévében összeállított egy komplex (programokat, versenyeket, táborokat tartalmazó) pályázati projektet, amelyet a Nemzeti Kutatási, Fejlesztési és Innovációs Hivatalhoz (NKFIH) nyújtott be támogatás elnyerése céljából. A pályázat sikeres volt, amelynek keretében minden szakmai egyesület vállalja egy-egy program megszervezését az érdeklôdô diákok részére. A hatékony 
kommunikáció és kapcsolattartás érdekében a FöCiK 2021. év elején létrehozza a FöCiK Facebook-oldalát és saját dedikált honlapját is (a www.focik.hu domain már le van foglalva). A projekt legnagyobb szabású, egész évre kiterjedô feladata az I. FöCiK Kárpátmedencei Természettudományos verseny megszervezése és lebonyolítása lesz. Reményeink szerint több mint 200 középiskolás csapat (4 fôs) fog elindulni a versenyen. A hat internetes forduló után kialakuló 10 legjobb csapat részére egy hetes tábort szervezünk a Bakony-Balaton Geoparkba sok szakmai túrával és egyéb programmal. Az internetes fordulók kérdéseit négy földtudományi témakörben állítjuk össze (1. a Föld, 2. a víz, 3. a fenntarthatóság és 4. a földrajz,

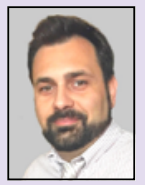

Dr. Nagy Levente föosztályvezetố

Agrárminisztérium Földügyi és Térinformatikai Fôosztály térképészet és távérzékelés). A verseny meghirdetésére a Föld napján (április 22-én) kerülne sor. A döntőt a novemberben megrendezésre kerülő Földtudományos Forgatag programjába fogjuk illeszteni, a média jelenlétének biztosítása mellett. Társaságunk önálló programja az EFGN2021 egész napos, szakmai-tudományos ismeretterjesztő előadásokból álló előadóülés megszervezése és lebonyolítása lesz, e mellett közremúködünk a verseny kér déseinek összeállításában is.

Társaságunknak 2021. év második felében talán lesz lehetôsége arra, hogy megbeszélést kezdeményezzünk együttmûködési lehetôségekrôl a szakágazat fơhhatósági vezetôivel, lehetôség szerint államtitkári szinten. A 2020. év egészében véve úgy telt

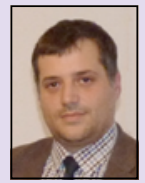

Dr. Tóth Balázs fốosztályvezetố

Miniszterelnökség Ingatlan-nyilvántartási és Térképészeti Főosztály el, hogy egyáltalán nem tudtunk felsôbb szintű vezetôkkel találkozni, megbeszélést folytatni. Reméljük, hogy 2021-ben a Covid-19 világjárvány megszúnése után teljes egészében a szakmai munkára lehet az erőforrásokat koncentrálni.

\section{Tisztelt Olvasóink!}

Feladataink megvalósításában továbbra is számítunk a szakma képviselőinek támogató együttmúködésére, szakértelmére a közös célok sikeres elérése érdekében.

Minden kedves kollégánknak, partnerünknek, valamint a Geodézia és Kartográfia olvasóinak jó egészséget és sok sikert kívánunk a 2021-es évben!

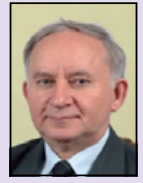

Dr. Ádám József elnök

Magyar Földmérési, Térképészeti és Távérzékelési Társaság 